\section{Policy-led public procurement: does strategic procurement deliver?}

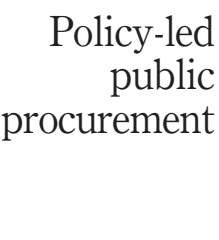

Christine Mary Harland

Dipartimento di Ingegneria Gestionale, Politecnico di Milano, Milan, Italy

Michael EBig

Department of Purchasing and Supply Management, Bundeswehr University Munich, Neubiberg, Germany

Jane Lynch

Cardiff Business School, Cardiff University, Cardiff, UK, and

Andrea Patrucco

Florida International University, Miami, Florida, USA
Received 31 May 2021 Accepted 9 June 2021

\section{Policy-led public procurement}

Public procurement can be leveraged to impact on business, the economy and society to support and can even lead broader government policy implementation (Harland et al., 2019; Glas et al., 2017). Examples of this include stimulating innovation (Wesseling and Edquist, 2018) and encouraging small-business entrepreneurship (Glas and Eßig, 2018; Di Mauro et al., 2020). Public procurement can be a mechanism for delivering better social outcomes (Grandia and Meehan, 2017; Uenk and Telgen, 2019), wider sustainability issues (AdjeiBamfo et al., 2019; Sönnichsen and Clement, 2020) and can play a role in encouraging social responsibility in private sector organisations (Flammer, 2018; Ma et al., 2020). Targeted public procurement can impact on employment (Flynn, 2018; Wontner et al., 2020). In several countries, public procurement has been shown to improve quality of local public services and economic development (Vecchiato and Roveda, 2014; Uyarra et al., 2020). Use of domestic suppliers in public contracts impacts national economies (Uyarra et al., 2014). If used strategically, public procurement can promote competition in supply markets (Patrucco et al., 2017).

Last but not least, the recent Covid-19 pandemic has shown how public procurement becomes instrumental in mitigating effects of emergencies (Handfield et al., 2020). In emergencies, governments have powers to intervene and override normal procurement arrangements (Atkinson et al., 2020), and they can lead a coordinated response to minimise the impact of disruption of supply of critical goods and services (Vecchi et al., 2020). We term all these goals and achievements as policy-led public procurement.

\section{Policy goals, regulation and value for money}

Although there is not an agreed single definition of public procurement, there is a clear understanding that it is interrelated with legal authority and regulation (Graells, 2015). In recent years, this regulation has been used explicitly as a strategic policy instrument, for example, as stated in the European regulation Directive 2014/24/EU:

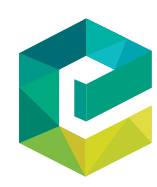

Journal of Public Procurement Vol. 21 No. 3, 2021

pp. $221-228$
C Emerald Publishing Limited 1535-0118 DOI 10.1108/JOPP-09-2021-089 
JOPP

21,3

222

Figure 1.

Triangle framework for procurement management
Public procurement plays a key role in the Europe 2020 strategy [. . . ] for smart, sustainable and inclusive growth [...], as one of the market-based instruments to be used to achieve smart, sustainable and inclusive growth while ensuring the most efficient use of public funds.

This quote illuminates a potential conflict between addressing strategic goals and the efficient use of public funds. Regulation enshrines awarding procedures and criteria as instruments to influence public buying behaviour. According to the regulation above, awarding should focus on the "most economically advantageous tender" (MEAT) criteria, another term for best value for money. As a result, public procurement is a complex system with different, and sometimes competing, managerial dimensions. Schapper et al. (2006) developed a triangular shaped framework consisting of strategic management, performance management and process management for public supply. For this special issue in the Journal of Public Procurement, we discuss the role of public procurement as a government policy lever by adapting this triangle framework where policy goals are featured at the top (Figure 1).

While there are different perspectives on positioning the triangle corners, there are some underlying principles:

- First, regulation is often seen as a dominant issue in public procurement practice (Decarolis and Giorgiantonio, 2015). It is argued that both procurement instruments (e.g. framework agreements; Petersen et al., 2020) as well as policy goals are put into action through introduction of new regulation.

- Second, some authors define "value for money" beyond mere cost savings, as the most important driver of public procurement (Loader, 2007; Dimitri, 2013). They argue that policy goals, as well as regulatory guidelines, are part of the desired outcome; this suggests a wider impact of value (Snider and Rendon, 2008).

- Third, other authors highlight operational implementation problems in balancing trade-offs between efficiency and effectiveness (Keränen, 2017; Keulemans and Van

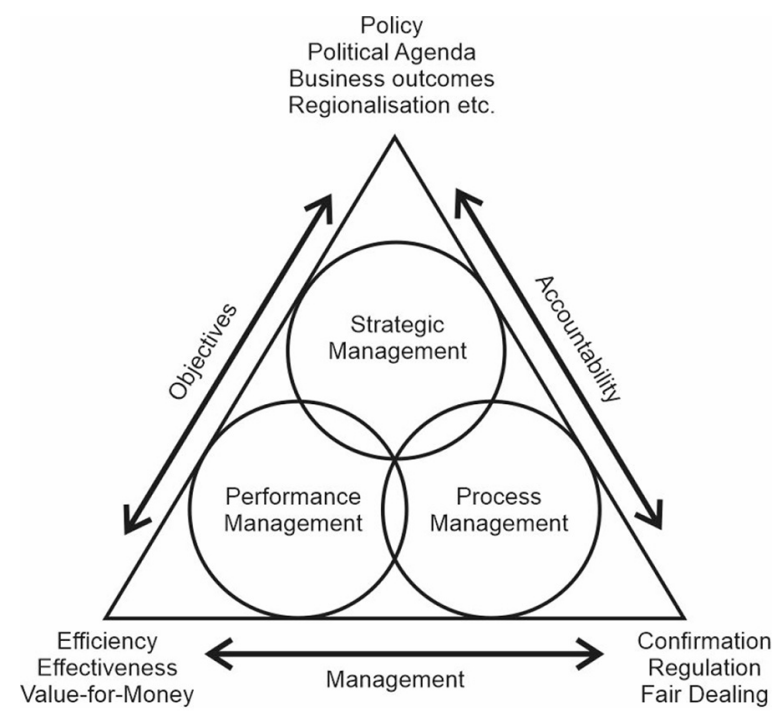

Source: Adapted from Schapper et al. (2006) 
de Walle, 2017; Tkachenko et al., 2018; Plaček et al., 2019; Wang et al., 2020; Patrucco et al., 2020). Implementation of policy goals in public procurement requires instruments and appropriate performance measures which may be absent (Patrucco et al., 2016; Flynn, 2018).

Policy-led
public
procurement

223

This special issue titled "Public procurement as a government policy lever" explores the positioning of policy goals, relative to other goals of procurement. However, thanks to the received contributions, it informs not only which policy goals should be included in public procurement practice, but also how public procurement might evolve to contribute strategically to government policymaking.

In the following, we provide a short overview of the papers included in this special issue and discuss how they inform policy-led procurement. This allows us to draw initial conclusions on how they contribute to further develop the triangle framework.

\section{Articles within this special issue}

The articles included in the Special Issue provide complementary perspectives on several policy-led public procurement themes including small business innovation, gender equity in public contracting, inclusion of minorities, and promotion of sustainability.

In his study, Selviaridis (Paper 1) focuses attention on the role that pre-commercial procurement $(\mathrm{PCP})$ plays in influencing activities, capabilities and behaviours of actors participating in the public innovation process. While prior PCP research is underpinned by theoretical frameworks of market failure (Suhonen et al., 2019), this article examines the role and capacity of PCP in addressing systemic failures impeding the process of innovation. The author finds that, thanks to public funding initiatives (i.e. the UK Small Business Research Initiative - SBRI), it is possible to stimulate and improve connectivity and research and development (R\&D) related interactions and cooperation. This brings greater opportunities for small firms to access relevant innovation ecosystems, building up their knowledge and capabilities to explore possible routes to market. Selviaridis (Paper 1) identifies several challenge areas that policymakers should address to improve future implementation of innovation-led procurement policies (Uyarra et al., 2020).

Orser (Paper 2) explores the extent to which women-owned enterprises are underrepresented among SMEs as suppliers to Canadian Government. Specifically, she examines barriers to public procurement - as perceived by small business owners - and whether this varies between genders. Gender-based analysis of public expenditures, purchases and gender-responsive PP are new to many governments that seek to support United Nations Sustainable Development Group (UNSDG) objectives. Outside Canada, sector-specific outreach strategies are designed to increase participation of women-owned businesses in federal contracting. This recommendation is consistent with the American Women-Owned Small Business (WOSB) Federal Contracting Program (Dilger, 2021).

Based on a study in Nigeria, Ausuquo (Paper 3) deals with a long-debated public procurement topic - the impact of governance quality on public infrastructure procurement. Good governance is crucial for ensuring effective and efficient provision of infrastructure, as it promotes accountability, reduces corruption, minimises resource wastage through inefficiency and ensures that resource allocations reflect national development priorities (Burger and Hawkesworth, 2011; Hueskes et al., 2017). However, studies of the impact of governance quality on public infrastructure financing are limited. Through this study, the author seeks to determine the impact of public sector corruption on public infrastructure expenditure. Accepting limitations of the time- period covered and that a single country perspective is taken, the study concludes that corruption, which is an indicator of 
JOPP 21,3

governance quality, plays a significant role in determining public resource allocation to infrastructure procurement in Nigeria. It also confirms that infrastructure procurement is particularly prone to corruption and poor governance, perhaps more so than other categories of spend.

The article by Allen (Paper 4) contributes to extant literature on public procurement by empirically addressing the evolution of procurement as a government policy lever in New Zealand, demonstrating how policy pragmatism can ensure a shift without a complete overhaul of a complex system. New Zealand has significant equity issues, especially related to its indigenous Maori population, and procurement is being used increasingly as a lever to improve equity. This article examines how New Zealand embeds policy in public procurement to pursue "public value" as a lever for delivering social and other economic outcomes (Grandia and Meehan, 2017). Consequently, a more strategic form of public procurement emerges. Using secondary data, Allen proposes that policy pragmatism or "bricolage" has enabled New Zealand to move reasonably smoothly from a "purist" approach to procurement policy to one that is more open to other forms of policy instrument, namely, social procurement and green or sustainable procurement. From a practical standpoint, there are indications here that it is not impossible to shift procurement policy direction while retaining strong procurement frameworks.

Finally, Schotanus (Paper 5) focuses on how short-term government procurement policies contribute to reach sustainability objectives (sustainable public procurement - SPP; Sönnichsen and Clement, 2020) through the design of environmental-friendly tenders. The author compares tenders from six months before and after the release of a report on inclusion of environmental concerns from the Dutch Central Government and evaluates the impact on the type of environmental features requested. The findings contribute to the academic debate on the value and effective implementation of SPP policies (Grandia and Kruyen, 2020), based on policy theory. In addition, while previous studies have largely focused on barriers and drivers of SPP (DelMonico et al., 2018), this study is able to offer a unique quantitative analysis at state level on the actual short-term effects on tenders of a policy aimed at altering the state's procurement procedures.

\section{Reshaping the policy "triangle"}

Policy goals are primary levers for strategic development of public procurement. However, all the articles included in this issue demonstrate that policy goals need to be implemented effectively for them to have any impact.

The articles by Allen and Orser focus on broader government policies (i.e. minority inclusion and gender representation), discussing how procurement policies should incentivise implementation of government policy instruments that subsequently contribute to the realisation of public procurement strategies at government level. Ausquo focuses more on regulatory aspects, looking at how the implementation of policies within procurement processes contributes to better monitoring of compliance to regulation (i.e. reduction of corruption). Selviaridis and Schotanaus' work focus on public procurement strategy implementation, examining how specific public procurement goals (i.e. innovation and sustainability) can be achieved through introduction of policies that push suppliers to deliver performance in strategic areas.

Prior strategic and public management research demonstrates that policy initiatives need to address the strategy implementation process (Klijn and Koppenjan, 2000). Implementation can be through financially-oriented mechanisms to influence resource 
capability, and information-oriented mechanisms to influence behaviour (Harland et al., 2019).

From the contributed papers and ensuing debate, we now suggest an adaptation of the Schapper et al. (2006) triangle framework (represented in Figure 2). Policy-led public procurement is not only the formulation of new goals, such as enhanced green and social sustainability, or promotion of innovation through suppliers, it is also the management of these issues within the public procurement system including planning, realising and measuring success i.e. performance management (Grandia and Meehan, 2017; Patrucco et al., 2020). As a result, the contract awarding process is an instrument which executes and delivers the outputs and outcomes of these policy initiatives. To illustrate what this looks like in practice, Figure 2 also maps how the five papers included in the Special Issue are positioned in this adapted framework.

\section{Conclusions and implications for future research}

This special issue provides international perspectives of how public procurement research is addressing policy-led procurement. Understanding procurement as a strategic lever has been considered in the private sector for some time (Brandon-Jones and Knoppen, 2018), and it has now become a government priority as well, especially in the COVID-19 era (Guarnieri and Gomes, 2019). The articles included in this issue offer a clear direction for future research to investigate public policy, policy implementation and the role of public procurement as a lever of policy implementation. Policy goals, their formulation and implementation are public duties (Snider and Rendon, 2008). More interdisciplinary research (e.g. with political and social sciences, and public administration) is required to understand how public procurement can be developed further as a policy lever.

Instead of arguing that regulation is the "only" way to implement policy goals in contract awarding procedures, a systematic approach is required to embrace public supplier performance management, including broader aspects of public procurement, such as supply market knowledge, collaborative relationships and long-term orientation (Loader, 2007; Keränen, 2017; Suhonen et al., 2019; Wesseling and Edquist, 2018; Uenk and Telgen, 2019). The articles in this special issue deliver important findings which we hope will encourage opportunities for further research.

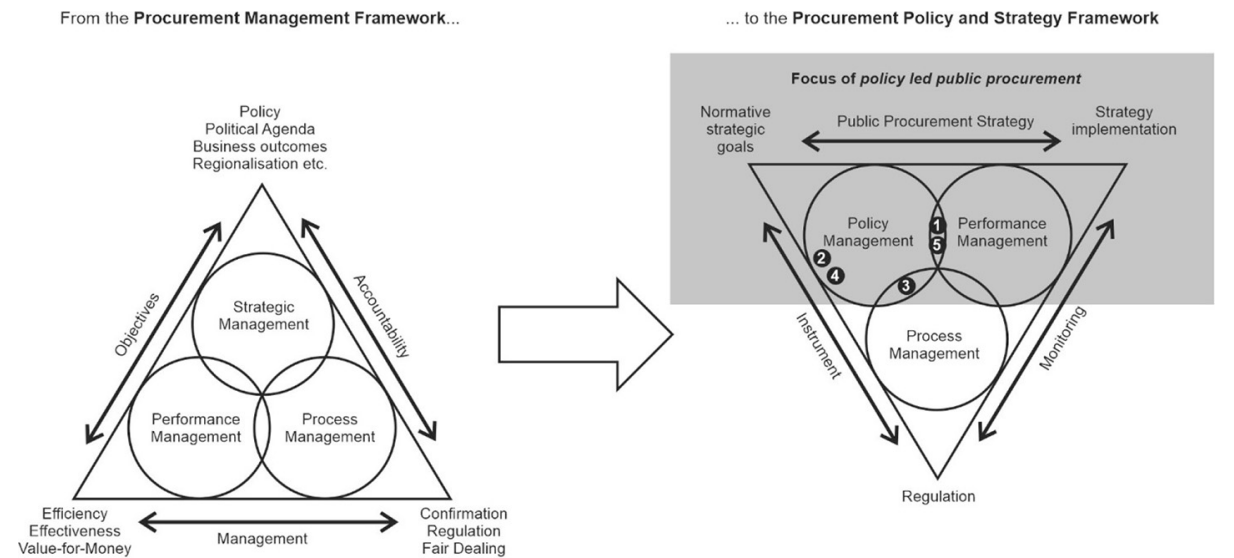

Figure 2.

Adapted triangle framework for procurement policy and strategy 
JOPP

21,3

\section{References}

Adjei-Bamfo, P., Maloreh-Nyamekye, T. and Ahenkan, A. (2019), "The role of e-government in sustainable public procurement in developing countries: a systematic literature review", Resources, Conservation and Recycling, Vol. 142, pp. 189-203.

Atkinson, C.L., McCue, C., Prier, E. and Atkinson, A.M. (2020), "Supply chain manipulation, misrepresentation, and magical thinking during the COVID-19 pandemic", The American Review of Public Administration, Vol. 50 Nos 6/7, pp. 628-634.

Brandon-Jones, A. and Knoppen, D. (2018), "The role of strategic purchasing in dynamic capability development and deployment: a contingency perspective", International Journal of Operations and Production Management, Vol. 38 No. 2, pp. 446-473.

Burger, P. and Hawkesworth, I. (2011), "How to attain value for money: comparing PPP and traditional infrastructure public procurement”, OECD Journal on Budgeting, Vol. 11 No. 1, pp. 91-146.

Decarolis, F. and Giorgiantonio, C. (2015), "Local public procurement regulations: the case of Italy", International Review of Law and Economics, Vol. 43, pp. 209-226.

Delmonico, D., Jabbour, C.J.C., Pereira, S.C.F., de Sousa Jabbour, A.B.L., Renwick, D.W.S. and Thomé, A. M.T. (2018), "Unveiling barriers to sustainable public procurement in emerging economies: evidence from a leading sustainable supply chain initiative in Latin America", Resources, Conservation and Recycling, Vol. 134, pp. 70-79.

Di Mauro, C., Ancarani, A. and Hartley, T. (2020), "Unravelling SMEs' participation and success in public procurement”, Journal of Public Procurement, Vol. 20 No. 4, pp. 377-401.

Dilger, R.J. (2021), "SBA Women-Owned small business federal contracting program", congressional research service report, R46322", available at https://fas.org/sgp/crs/misc/R46322.pdf

Dimitri, N. (2013), "Best value for money" in procurement”, Journal of Public Procurement, Vol. 13 No. 2, pp. 149-175.

Flammer, C. (2018), "Competing for government procurement contracts: the role of corporate social responsibility”, Strategic Management Journal, Vol. 39 No. 5, pp. 1299-1324.

Flynn, A. (2018), "Measuring procurement performance in Europe", Journal of Public Procurement, Vol. 18 No. 1, pp. 2-13.

Flynn, A. (2018), "Investigating the implementation of SME-friendly policy in public procurement", Policy Studies, Vol. 39 No. 4, pp. 422-443.

Glas, A.H. and EBig, M. (2018), "Factors that influence the success of small and medium-sized suppliers in public procurement: evidence from a centralized agency in Germany", Supply Chain Management: An International Journal, Vol. 23 No. 1, pp. 65-78.

Glas, A.H., Schaupp, M. and Essig, M. (2017), “An organizational perspective on the implementation of strategic goals in public procurement”, Journal of Public Procurement, Vol. 17 No. 4, pp. 572-605.

Graells, A.S. (2015), Public Procurement and the EU Competition Rules, Bloomsbury Publishing.

Grandia, J.J. and Kruyen, P.P. (2020), "Assessing the implementation of sustainable public procurement using quantitative text-analysis tools: a large-scale analysis of Belgian public procurement notices", Journal of Purchasing and Supply Management, Vol. 26 No. 4, p. 100627.

Grandia, J. and Meehan, J. (2017), "Public procurement as a policy tool: using procurement to reach desired outcomes in society", International Journal of Public Sector Management, Vol. 30 No. 4, pp. 302-309.

Guarnieri, P. and Gomes, R.C. (2019), "Can public procurement be strategic? A future agenda proposition", Journal of Public Procurement, Vol. ahead-of-print No. ahead-of-print, pp. 295-321.

Handfield, R., Finkenstadt, D.J., Schneller, E.S., Godfrey, A.B. and Guinto, P. (2020), “A commons for a supply chain in the post-COVID-19 era: the case for a reformed strategic national stockpile", The Milbank Quarterly, Vol. 98 No. 4, pp. 1058-1090. 
Harland, C., Telgen, J., Callender, G., Grimm, R. and Patrucco, A. (2019), "Implementing government policy in supply chains: an international coproduction study of public procurement", Journal of Supply Chain Management, Vol. 55 No. 2, pp. 6-25.

Hueskes, M., Verhoest, K. and Block, T. (2017), "Governing public-private partnerships for sustainability: an analysis of procurement and governance practices of PPP infrastructure projects", International Journal of Project Management, Vol. 35 No. 6, pp. 1184-1195.

Keränen, O. (2017), "Roles for developing public-private partnerships in centralized public procurement”, Industrial Marketing Management, Vol. 62, pp. 199-210.

Keulemans, S. and Van de Walle, S. (2017), "Cost-effectiveness, domestic favouritism and sustainability in public procurement: a comparative study of public preferences", International Journal of Public Sector Management, Vol. 30 No. 4, pp. 328-341.

Klijn, E.H. and Koppenjan, J.F. (2000), "Public management and policy networks: foundations of a network approach to governance", Public Management: An International Journal of Research and Theory, Vol. 2 No. 2, pp. 135-158.

Loader, K. (2007), "The challenge of competitive procurement: value for money versus small business support", Public Money and Management, Vol. 27 No. 5, pp. 307-314.

Ma, Y., Liu, Y., Appolloni, A. and Liu, J. (2020), "Does green public procurement encourage firm's environmental certification practice? The mediation role of top management support", Corporate Social Responsibility and Environmental Management, Vol. 28 No. 3.

Patrucco, A.S., Agasisti, T. and Glas, A.H. (2020), "Structuring public procurement in local governments: the effect of centralization, standardization and digitalization on performance", Public Performance and Management Review, pp. 1-27.

Patrucco, A.S., Luzzini, D. and Ronchi, S. (2016), "Evaluating the effectiveness of public procurement performance management systems in local governments", Local Government Studies, Vol. 42 No. 5, pp. 739-761.

Patrucco, A.S., Luzzini, D., Ronchi, S., Essig, M., Amann, M. and Glas, A.H. (2017), “Designing a public procurement strategy: lessons from local governments", Public Money and Management, Vol. 37 No. 4, pp. 269-276.

Petersen, O.H., Jensen, M.D. and Bhatti, Y. (2020), "The effect of procurement centralization on government purchasing prices: evidence from a field experiment", International Public Management Journal, pp. 1-19.

Plaček, M., Nemec, J., Ochrana, F., Schmidt, M. and Pǔček, M. (2019), “Analysis of factors of overpricing in public procurement: a study for low-performing EU countries”, International Journal of Public Administration, Vol. 43 No. 4, pp. 350-360.

Schapper, P.R., Veiga Malta, J.N. and Gilbert, D.L. (2006), “An analytical framework for the management and reform of public procurement”, Journal of Public Procurement, Vol. 6 Nos 1/2, pp. 1-26.

Snider, K.F. and Rendon, R.G. (2008), "Public procurement policy: implications for theory and practice", Journal of Public Procurement, Vol. 8 No. 3, pp. 310-333.

Sönnichsen, S.D. and Clement, J. (2020), "Review of green and sustainable public procurement: towards circular public procurement", Journal of Cleaner Production, Vol. 245, p. 118901.

Suhonen, N., Tammi, T., Saastamoinen, J., Pesu, J., Turtiainen, M. and Okkonen, L. (2019), "Incentives and risk-sharing in public procurement of innovations: towards contracting strategy framework", Journal of Public Procurement, Vol. 19 No. 2, pp. 129-145.

Tkachenko, A., Yakovlev, A. and Rodionova, Y. (2018), "Organizational forms and incentives in public procurement: natural experiment at a large public sector organization in Russia”, International Journal of Public Administration, Vol. 41 No. 14, pp. 1157-1168.

Uenk, N. and Telgen, J. (2019), "Managing challenges in social care service triads - exploring public procurement practices of Dutch municipalities", Journal of Purchasing and Supply Management, Vol. 25 No. 1, pp. 5-17. 
JOPP

21,3

Uyarra, E., Zabala-Iturriagagoitia, J.M., Flanagan, K. and Magro, E. (2020), "Public procurement, innovation and industrial policy: rationales, roles, capabilities and implementation", Research Policy, Vol. 49 No. 1, p. 103844.

Uyarra, E., Edler, J., Garcia-Estevez, J., Georghiou, L. and Yeow, J. (2014), "Barriers to innovation through public procurement: a supplier perspective”, Technovation, Vol. 34 No. 10, pp. 631-645.

Vecchi, V., Cusumano, N. and Boyer, E.J. (2020), "Medical supply acquisition in Italy and the United States in the era of COVID-19: the case for strategic procurement and public-private partnerships", The American Review of Public Administration, Vol. 50 Nos 6/7, pp. 642-649.

Vecchiato, R. and Roveda, C. (2014), "Foresight for public procurement and regional innovation policy: the case of Lombardy", Research Policy, Vol. 43 No. 2, pp. 438-450.

Wang, Q., Zhang, R. and Liu, J. (2020), "Price/time/intellectual efficiency of procurement: uncovering the related factors in Chinese public authorities", Journal of Purchasing and Supply Management, Vol. 26 No. 3, p. 100622.

Wesseling, J.H. and Edquist, C. (2018), "Public procurement for innovation to help meet societal challenges: a review and case study", Science and Public Policy, Vol. 45 No. 4, pp. 493-502.

Wontner, K.L., Walker, H., Harris, I. and Lynch, J. (2020), "Maximising community benefits" in public procurement: tensions and trade-offs", International Journal of Operations and Production Management, Vol. 40 No. 12, pp. 1909-1939.

\section{Corresponding author}

Christine Mary Harland can be contacted at: christinemary.harland@polimi.it

For instructions on how to order reprints of this article, please visit our website: 